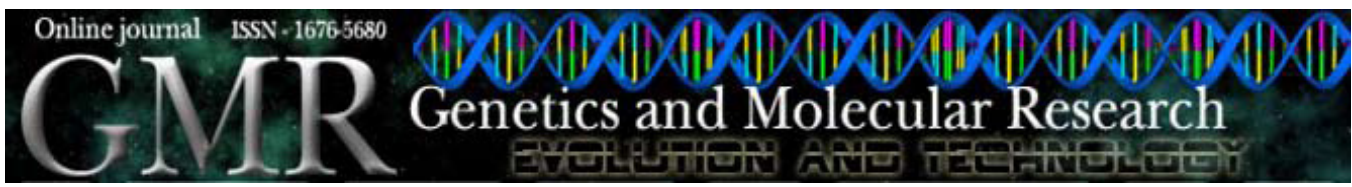

\title{
Effects of trans-10, cis-12 conjugated linoleic acid on gene expression and lipid metabolism of adipose tissue of growing pigs
}

\author{
A.A.F.B.V. José ${ }^{1}$, M.A.S. Gama ${ }^{2}$ and D.D.P. Lanna ${ }^{1}$ \\ ${ }^{1}$ Departamento de Zootecnia, Universidade de São Paulo, Piracicaba, SP, Brasil \\ ${ }^{2}$ Empresa Brasileira de Pesquisa Agropecuária, \\ Embrapa Gado de Leite, Juiz de Fora, MG, Brasil \\ Corresponding author: D.D.P. Lanna \\ E-mail: dplanna@esalq.usp.br
}

Genet. Mol. Res. 7 (2): 284-294 (2008)

Received December 14, 2007

Accepted February 6, 2008

Published April 1, 2008

ABSTRACT. The objective of the present study was to determine the effects of trans-10, cis-12 conjugated linoleic acid (CLA) in adipose tissue explant cultures of growing pigs on the following responses: lipogenesis (measured as rate of ${ }^{14} \mathrm{C}$-labeled glucose incorporation over a subsequent 2-h incubation in the presence or absence of insulin), lipolysis (release of non-esterified fatty acid over a 2-h incubation in the presence or absence of isoproterenol), activities of lipogenic enzymes, and mRNA abundance of fatty acid synthase (FAS). Adipose tissue explants from nine growing pigs $(78 \pm 3 \mathrm{~kg}$ ) were cultured in 199 medium with insulin, dexamethasone and antibiotics for 4, 12, 24, and $48 \mathrm{~h}$. The treatments were 1) control: $100 \mu \mathrm{M}$ polyvinyl alcohol (PVA); 2) pGH: $100 \mathrm{ng} / \mathrm{mL}$ porcine growth hormone (pGH) plus $100 \mu \mathrm{M}$ PVA; 3) CLA200: $200 \mu \mathrm{M}$ trans-10, cis-12 CLA; 4) CLA50: $50 \mu \mathrm{M}$ trans-10, cis-12 CLA, and 5) LA: $200 \mu \mathrm{M}$ linoleic acid. Fatty acids were added along with PVA (2:1), respectively, for $24 \mathrm{~h}$. Explants were collected after each culture period and assayed for lipogenesis. Transcripts of FAS mRNA were quantified by real-time RT-PCR after 24 and $48 \mathrm{~h}$. Lipolysis and activities of FAS, glucose 6-phosphate dehydrogenase, 6-phosphogluconate dehydrogenase, and NADP-malate dehydrogenase were determined after $48 \mathrm{~h}$. As expected, glucose incorporation was decreased $(\mathrm{P}<0.05)$ in response to $\mathrm{pGH}$ treatment (positive control). LA 
had no effect on any parameter evaluated. Treatment with trans-10, cis-12 CLA decreased FAS activity $(\mathrm{P}<0.05)$, but NADPH-generating enzymes were unaffected by treatments. Consistent with reduction in FAS activity, both lipid synthesis and FAS mRNA abundance were reduced with chronic CLA treatment, pGH increased baseline and stimulated lipolysis $(\mathrm{P}<0.05)$ after $48 \mathrm{~h}$ of culture, while CLA treatment had no effect on nonesterified fatty acid release. Results of this study showed that trans-10, cis-12 CLA alters lipogenesis but has no effect on lipolysis in cultures of pig adipose tissue.

Key words: Conjugated linoleic acid; Adipose tissue explants; Lipogenesis; Bioactive fatty acid; Swine

\section{INTRODUCTION}

Several studies have demonstrated that physiological effects of conjugated linoleic acid (CLA) go beyond the anti-tumor effect initially observed in bovine meat (Pariza et al., 1979). CLA isomers are found mainly in ruminant products (e.g., milk and meat) and are intermediates in the biohydrogenation pathways of linoleic acid (LA) in the rumen. Nearly twenty different isomers of CLA have been identified in milk and meat from ruminants. Studies have shown that part of CLA effects are related to an anti-lipogenic action, with alteration of body composition in mice (Park et al., 1997) and swine (Dugan et al., 1997, 1999; Ostrowska et al., 1999; Bee, 2000; Thiel-Cooper et al., 2001) and changes in milk fat content and profile of dairy cows (Chouinard et al., 1999; Giesy et al., 1999; Baumgard et al., 2000; Medeiros et al., 2000). Most of these effects were shown to be associated with a decreased activity of lipogenic enzymes (Piperova et al., 2000; Lin et al., 2004; Hayashi et al., 2007).

trans-10, cis-12 CLA has been identified as the CLA isomer responsible for reducing milk fat synthesis (Baumgard et al., 2000) and mRNA concentration of several lipogenic enzymes in the mammary gland (Baumgard et al., 2002; Peterson et al., 2003). Similarly, this CLA isomer can also affect the body composition of mice, with reduction in fat deposition and activity of the lipoprotein lipase enzyme in 3T3-L1-cultured murine adipocytes (Park et al., 1999). Other effects of trans-10, cis-12 CLA include: reduced activity and mRNA abundance of stearoyl-CoA desaturase (SCD) (Lee et al., 1998; Choi et al., 2000; Park et al., 2000; Baumgard et al., 2000), reduced lipid accumulation in human adipocytes (Brown and McIntosh, 2003), and increased LDL:HDL ratio in healthy humans (Tricon et al., 2004). However, most of the studies involving CLA were conducted with different animal models using a mixture of several isomers at different doses, usually with in vivo administration followed by in vitro evaluation or in vitro administration with cell lines (e.g., 3T3-L1). Thus, it is not surprising that results are varied or even contradictory.

Cultures of tissue explants are an important tool for studying the mechanisms of action of CLA, since they allow the performance of several simultaneous evaluations. In regard to primary cultures, there are advantages in terms of similarity of the responses in comparison with cell lines which can undergo mutation. In growing pig, adipose tissue is very important in both physiological and economical terms. This tissue stores the reserves of body energy, pre- 
dominantly as lipids (Bauman and Davis, 1975). Lipid synthesis in swine occurs predominantly in the adipose tissue by de novo pathway using glucose as substrate. In general, changes in the rate of lipid synthesis parallel changes in the enzyme activities (Sinnett-Smith et al., 1979) such as fatty acid synthase (FAS), considered a key regulator of this biochemical pathway.

The objective of this study was to determine the effect of trans-10, cis-12 CLA on lipid metabolism using cultures of subcutaneous adipose tissue explants obtained from growing pigs.

\section{MATERIAL AND METHODS}

\section{Pig adipose tissue culture explants}

Nine Landrace $x$ Large White castrated male pigs with an average weight of $78 \pm 3 \mathrm{~kg}$ were humanely slaughtered in agreement with Animal Care and Use Committee of the University of São Paulo and used as a source of adipose tissue. Animals were fed diet containing $78 \%$ corn and 19\% soybean meal, which had 3.3\% ether extract (on a dry matter basis). Approximately $7 \%$ of the metabolizable energy came from lipids, and animals had free access to feed and water until slaughter. About $20 \mathrm{~g}$ subcutaneous adipose tissue was removed post mortem from the upper leg (ham) of each pig and immediately placed in transport buffer ( $25 \mathrm{mM}$ HEPES, $0.15 \mathrm{M} \mathrm{NaCl}, \mathrm{pH} 7.4$, at $37^{\circ} \mathrm{C}$ ). In the laboratory, 50 to $100 \mathrm{mg}$ (explants) of the intermediate layer from subcutaneous adipose tissue were aseptically removed and placed into multi-well plates containing Medium 199 with Earle's salt, $0.1 \mathrm{~g} / \mathrm{L}$ L-glutamine, $25 \mathrm{mM}$ HEPES and 25 $\mathrm{mM}$ sodium bicarbonate, $\mathrm{pH} 7.4$, supplemented with antibiotics and maintained at $37^{\circ} \mathrm{C}$ (Lanna et al., 1995). These explants were used for each hormonal treatment for each pig. The treatments were 1) control: cultures were supplemented with $0.1 \mu \mathrm{g} / \mathrm{mL}$ insulin, $10 \mathrm{nM}$ dexamethasone and $100 \mu \mathrm{M}$ polyvinyl alcohol (PVA, Sigma Chemical); 2) growth hormone (pGH) cultures received $0.1 \mu \mathrm{g} / \mathrm{mL}$ pGH (porcine recombinant growth hormone - Reporcin ${ }^{\circledR}$, Southern Cross Biotech), $0.1 \mu \mathrm{g} / \mathrm{mL}$ insulin, $10 \mathrm{nM}$ dexamethasone and $100 \mu \mathrm{M}$ PVA; 3) CLA200 cultures received 100 $\mathrm{ng} / \mathrm{mL}$ insulin, $10 \mathrm{nM}$ dexamethasone and $200 \mu \mathrm{M}$ trans-10, cis-12 CLA; 4) CLA50 cultures received $100 \mathrm{ng} / \mathrm{mL}$ insulin, $10 \mathrm{nM}$ dexamethasone and $50 \mu \mathrm{M}$ trans-10, cis-12 CLA, and 5) LA cultures received $100 \mathrm{ng} / \mathrm{mL}$ insulin, $10 \mathrm{nM}$ dexamethasone and $200 \mu \mathrm{M}$ LA (Sigma).

The cultures were incubated in $5 \% \mathrm{CO}_{2}$ at $37^{\circ} \mathrm{C}$ for $4,12,24$, and $48 \mathrm{~h}$. Explants from each pig and treatment were collected and assayed for lipogenesis. Other explants were collected after 24 or $48 \mathrm{~h}$ and assayed by real-time RT-PCR (reverse transcriptase-polymerase chain reaction) for FAS mRNA transcripts. Lipolysis and enzyme activities of FAS, glucose 6-phosphate dehydrogenase (G-6PDH), 6-phosphogluconate dehydrogenase (6-PGDH) and NADP-malate dehydrogenase (NADP-MD) were determined after $48 \mathrm{~h}$.

Fatty acids were associated with PVA in order to introduce them into the culture. CLA or LA were diluted in dimethyl sulfoxide (Sigma) and added in $2.5 \mathrm{mM}$ PVA in phosphatebuffered saline, $\mathrm{pH} 7.4$, under aseptic conditions at $37^{\circ} \mathrm{C}$, for $24 \mathrm{~h}$. The control treatment, with PVA only, was carried out in the same way, except for the addition of fatty acid. The fatty acid:PVA ratio was 2:1 and the CLA doses were obtained in preliminary assays (José et al., 2007). The concentration of the supplement containing CLA in the CLA200 treatment was adjusted to $212 \mu \mathrm{M}$ in order to allow a final concentration of $200 \mu \mathrm{M}$ trans-10, cis-12 CLA isomer. This CLA supplement was kindly donated by Dr. Dale Bauman (Baumgard et al., 2000) and its composition is presented in Table 1. 


\begin{tabular}{lc} 
Table 1. Conjugated linoleic acid profile. & \\
\hline Fatty acids & $\mathrm{g} / 100 \mathrm{~g}$ \\
\hline $16: 0$ & 1 \\
$18: 0$ & 0.3 \\
$18: 1$ cis- 9 & 0.4 \\
$18: 2$ cis- 9, cis-12 & 0.4 \\
$18: 2$ cis- 9, trans -11 & 2.2 \\
$18: 2$ trans- 10, cis-12 & 94.5 \\
Not detected & 1.2
\end{tabular}

Source: Natural Lipids Hovdebygda, Norway Ltd.

\section{Lipogenesis assay}

After incubation, the explants were transferred to scintillation vials containing $2 \mathrm{~mL}$ lipogenesis medium (1X Krebs Ringer buffer, $0.65 \mathrm{mM} \mathrm{CaCl}_{2}, 10 \mathrm{mM}$ HEPES, $10 \mathrm{mM}$ glucose and $0.5 \mu \mathrm{Ci} / \mathrm{mL}$ glucose $\mathrm{D}-\left[{ }^{14} \mathrm{C}(\mathrm{U})\right]$ - Amersham Biosciences; $\mathrm{pH}$ 7.4) and incubated for $2 \mathrm{~h}$ in $5 \% \mathrm{CO}_{2}$ at $37^{\circ} \mathrm{C}$ in a shaking water bath. This was done in triplicate for a) baseline lipogenesis: no insulin was added and b) insulin lipogenesis: $1 \mu \mathrm{g} / \mathrm{mL}$ insulin. Subsequently, lipids were extracted from tissue explants according to Folch et al. (1957) with some modifications. Explants were transferred to extraction vials containing $5 \mathrm{~mL}$ of a $1: 2$ methanol:chloroform mixture and incubated for $1 \mathrm{~h}$ at room temperature. After that, $1 \mathrm{~mL} 1 \% \mathrm{NaCl}$ was added. After 12 to $16 \mathrm{~h}$ of incubation, the lower phase was collected and then transferred to scintillation vials where $0.5 \mathrm{~mL}$ hexane and $5 \mathrm{~mL}$ scintillation liquid were added (Sigma). Radiation was measured in an automatic scintillation counter (Beckman Instruments - LS 5000 TD - Liquid Scintillation System). Lipogenesis rate was expressed in nmoles of glucose incorporated per gram of tissue in $2 \mathrm{~h}$.

\section{Enzymatic activity assay}

The assay of the enzyme FAS was performed according to Ingle et al. (1973) with some modifications. Samples of cultured explants for each treatment were homogenized in a Polytron (Polytron - PT MR 21-00, Kinematica AG) using a 3-mL solution containing $0.15 \mathrm{M} \mathrm{KCl}, 50 \mathrm{mM}$ Tris-buffer, $1 \mathrm{mM}$ glutathione and $1 \mathrm{mM}$ EDTA buffer at $4^{\circ} \mathrm{C}$ and $\mathrm{pH}$ 7.4. FAS activity was calculated indirectly by spectrophotometry at $340 \mathrm{~nm}$ which indicates the rates of NADPH to NADP conversion in incubation tubes containing substrate, co-factors and the homogenate of the adipose tissue. The concentrations of the reagents were: $40 \mathrm{mM}$ potassium phosphate buffer plus EDTA, pH 6.8, $0.1 \mathrm{mM}$ malonyl CoA, $0.1 \mathrm{mM}$ acetyl CoA, $0.3 \mathrm{mM}$ NADPH and $0.4 \mathrm{mM}$ dithiothreitol. The assays of the enzymes NADP-MD, G-6PDH and 6-PGDH were performed according to Bauman et al. (1970) and Glock and McLean (1953), respectively. Protein concentration in the homogenate was determined by the biuret method (Gornall et al., 1949) using bovine serum albumin as standard. Enzymatic activities are reported as nmol. $\mathrm{min}^{-1} \cdot \mathrm{mg}$ cytosol protein ${ }^{-1}$.

\section{Real-time RT-PCR}

After 24 and $48 \mathrm{~h}$ of culture, 3-4 explants (around $30 \mathrm{mg}$ each) from each animal and treatment were collected, combined to approximately $100 \mathrm{mg}$, pulverized in liquid nitrogen and 
submitted to total RNA extraction with the Trizol reagent (Invitrogen). Samples were dissolved in RNAse-free water in duplicate and quantified by spectrophotometer at $260 \mathrm{~nm}$. Purity of total RNA was determined by the A260:A280 ratio. The integrity of each RNA sample was checked by electrophoresis on $1 \%$ agarose gels. cDNA samples were prepared from $1 \mu \mathrm{g}$ total RNA using oligo (dT) primer. The cDNA syntheses were performed with the SuperScript First-Strand Synthesis System for RT-PCR kit (Invitrogen) according to the supplier protocol.

PCR products containing $2 \mu \mathrm{L}$ cDNA were prepared in a final volume of $10 \mu \mathrm{L}$. In addition to templates, the reactions contained $1 \mathrm{X}$ Absolute ${ }^{\mathrm{TM}}$ QPCR SYBR ${ }^{\circledR}$ Green Mix ABgene and $0.25 \mu \mathrm{M}$ of the sense and antisense primers for each gene (50 cycles, initial denaturation at $95^{\circ} \mathrm{C}$ for $10 \mathrm{~s}$, followed by annealing at $56^{\circ} \mathrm{C}$ for $15 \mathrm{~s}$ and extension at $72^{\circ} \mathrm{C}$ for $20 \mathrm{~s}$ ). The same conditions were used in the programs of PCR for amplification of the FAS and of the $\beta$-actin fragments. The primers were designed for the amplification of $126 \mathrm{bp}$ of the cDNA of the FAS gene. The following oligonucleotide primers (Dialab Diagnóstico) were used: sense (5' CGG CTC ACA CAC CTT CGT 3') and antisense (5' TGC TCC ATG TCG GTG AAC T 3') and of $150 \mathrm{bp}$ for $\beta$-actin gene (5' TGG TGG GTA TGG GTC AGA A 3' - sense and 5' GCT CGT TGT AGA AGG TGT GG 3'- antisense). The quantifications were performed using a RotorGene 3000 (Corbett Research) (Plant Improvement Laboratory, CENA, USP). The relative quantification method was based on Pfaffl (2001), and the significance of the differences was estimated by pair-wise fixed reallocation randomization test using the Relative software tool (REST ${ }^{\circ}$ v.1.9.9), as described previously (Pfaffl et al., 2002).

\section{Lipolysis assay}

After $48 \mathrm{~h}$ of incubation, explants were collected and incubated in $2 \mathrm{~mL}$ lipolysis medium (1X Krebs Ringer buffer, $0.65 \mathrm{mM} \mathrm{CaCl}_{2}, 2.5 \mathrm{mM}$ HEPES, $5.6 \mathrm{mM}$ glucose and 3\% bovine serum albumin, $\mathrm{pH} 7.4)$ for $2 \mathrm{~h}$ in $5 \% \mathrm{CO}_{2}(\mathrm{v} / \mathrm{v})$ at $37^{\circ} \mathrm{C}$ in a shaking water bath. This was done in triplicate for the following treatments: a) baseline lipolysis: no stimulus and b) isoproterenol lipolysis: $10 \mu \mathrm{M}$ isoproterenol. Samples from the medium were then collected and analyzed for non-esterified fatty acid (NEFA C ${ }^{\circledR}$ kit, Wako Chemicals) by spectrophotometry. Absorbance values at $540 \mathrm{~nm}$ were converted into concentration $(\mu \mathrm{mol} / \mathrm{L}$ oleic acid) based on the standard curve, and NEFA concentrations were corrected for explants weight (g) and reported in $\mu$ moles of oleic acid per gram of tissue produced for $2 \mathrm{~h}$.

\section{Statistical analysis}

Repeated measures analysis of variance was used for the lipogenesis assay. The model included treatment, stimulus, time and their interactions as fixed effects and random effects of animal within treatment versus stimulus as the error term to test the treatments and stimulus effects, respectively. Since the time factor was not equally spaced, covariance structure type SP (POW) (time) was used (Littell et al., 1996). Data from lipolysis were analyzed according to a split plot model, where treatment was applied to plots (element) and stimulus in sub-plots. For enzymatic activities, the analysis of variance was based on a model including treatment and animal. The Tukey test was used to compare treatments. Differences were considered to be significant when $\mathrm{P}<0.05$. All analyses were performed using Proc Mixed (SAS, 1999). 


\section{RESULTS AND DISCUSSION}

Treatment effects on ${ }^{14} \mathrm{C}$-glucose incorporation in cultures of adipose tissue explants incubated for $4,12,24$, and $48 \mathrm{~h}$ are shown in Table 2 . There were treatment and time effects $(\mathrm{P}<$ 0.001 ), but interactions among treatment, time and stimulus were not statistically significant.

\begin{tabular}{|c|c|c|c|c|c|c|c|c|c|}
\hline \multicolumn{10}{|c|}{ Treatment } \\
\hline & & & pGH & LA & & \multirow{3}{*}{\multicolumn{2}{|c|}{$\begin{array}{c}\text { CLA200 } \\
5568.6 \\
(1015.4)\end{array}$}} & & \\
\hline & & 5913.1 & 3816.9 & 5802.2 & & & & & \\
\hline & & (991.9) & $(1013.2)$ & (985.6) & & & & & \\
\hline \multicolumn{10}{|c|}{ Effects } \\
\hline $\mathrm{C}$ & CLA200 & CLA200 & CLA200 & $\mathrm{C}$ & CLA50 & CLA50 & $\mathrm{C}$ & LA & $\mathrm{C}$ \\
\hline $\mathrm{x}$ & $\mathrm{x}$ & $\mathrm{x}$ & $\mathrm{x}$ & $\mathrm{x}$ & $\mathrm{x}$ & $\mathrm{x}$ & $\mathrm{x}$ & $\mathrm{x}$ & $\mathrm{x}$ \\
\hline CLA200 & CLA50 & LA & pGH & CLA50 & LA & pGH & LA & pGH & pGH \\
\hline Ns & Ns & Ns & Ns & Ns & Ns & * & Ns & $*$ & r \\
\hline
\end{tabular}

Data are reported as means (SD) from cultures of adipose tissue explants $(\mathrm{N}=9)$. C: control $(100 \mu \mathrm{M}$ polyvinyl alcohol); pGH: $100 \mathrm{ng} / \mathrm{mL}$ porcine growth hormone; LA: $200 \mu \mathrm{M}$ linoleic acid; CLA50: $50 \mu \mathrm{M}$ trans-10, cis-12 conjugated linoleic acid. CLA200: $200 \mu \mathrm{M}$ trans-10, cis-12 CLA. Different probability between treatments $(* \mathrm{P}<$ 0.05 ; Ns: P > 0.05).

The rate of ${ }^{14} \mathrm{C}$ incorporation was decreased along the incubation periods (data not shown). This reduction was more pronounced than in other studies, but the values still remained high enough to demonstrate that explants were metabolically active. The rate of ${ }^{14} \mathrm{C}$ incorporation after $48 \mathrm{~h}$ of pGH treatment also indicates that cultures were responsive to the positive control. However, the inhibitory effect of pGH on lipid synthesis was lower than that observed in experiments conducted under the same conditions with either pig adipose tissue culture (Lanna et al., 1994; Etherton et al., 1995) or lactating cows (Lanna et al., 1995; Lanna and Bauman, 1999). Contrary to expectations, the lipogenesis rate was unaffected by CLA treatment in the present study and the reason for the lack of response to CLA is not clear. Several mechanisms have been proposed to explain the inhibitory effect of CLA on lipogenesis observed in some studies. Reductions in both key enzyme activities and substrate availability seem to be involved. The last hypothesis is consistent with the lower Glut 4 mRNA abundance in brown and white adipose tissues of mice treated with a mixture of CLA isomers, after 21 days of administration (Takahashi et al., 2002). In contrast, Satory and Smith (1999) observed that a mixture of CLA isomers (41\% cis-9, trans-11 and $44 \%$ trans- 10 , cis-12), at $6 \mu \mathrm{M}$, induced an accumulation of lipids by de novo pathway in the 3T3-L1 adipocyte cell line. On the other hand, Park et al. (1997) observed a reduction in lipase lipoprotein activity and an increased NEFA release using the same cell line, but with a higher dose $(100 \mu \mathrm{M})$ of a similar CLA isomer mixture (approximately 50\% cis-9, trans- 11 and 50\% trans-10, cis-12). It is likely that differences in doses can explain at least part of these contrasting responses. However, plenty of studies have consistently demonstrated the inhibitory effect of trans-10, cis-12 on lipogenesis. This effect seems to be associated with the interaction among the trans-10, cis-12 CLA and some transcription factors, such as the sterol regulatory element-binding protein (Takahashi et al., 2003). Although CLA treatment had no significant effect on lipid synthesis rate in the present study, FAS activity was reduced by the treatment with $200 \mu \mathrm{M}$ trans-10, cis-12 CLA $(\mathrm{P}<0.05$, Table 3). Ac- 
cordingly, FAS mRNA abundance was reduced by both CLA doses by $\sim 60$ and $50 \%$ in relation to control after 24 and $48 \mathrm{~h}$ of treatment, respectively (Table 4). As expected, pGH had a pronounced inhibitory effect on FAS activity, which is consistent with associated changes in FAS mRNA abundance observed after $48 \mathrm{~h}$ of treatment (Table 4). The magnitude of this response was even higher than that observed by Lanna et al. (1994).

Table 3. Lipogenic enzyme activities after 48 h of culture.
\begin{tabular}{lcccrr}
\hline Enzyme & $\mathrm{C}$ & $\mathrm{pGH}$ & Treatment \\
\cline { 2 - 6 } & $22(5.10)^{\mathrm{a}}$ & $6.7(5.60)^{\mathrm{b}}$ & $22.2(4.30)^{\mathrm{a}}$ & $17.1(4.70)^{\mathrm{a}, \mathrm{b}}$ & CLA200 \\
\hline FAS & $46.1(9.60)^{\mathrm{a}}$ & $43.9(14.0)^{\mathrm{a}}$ & $64(9.30)^{\mathrm{a}}$ & $58.1(10.7)^{\mathrm{a}}$ & $64.6(10.70)^{\mathrm{b}}$ \\
G-6PDH & $41.3(4.60)^{\mathrm{a}}$ & $44.5(5.70)^{\mathrm{a}}$ & $39.7(3.90)^{\mathrm{a}}$ & $45.2(5.70)^{\mathrm{a}}$ & $54.5(5.00)^{\mathrm{a}}$ \\
6-PGDH & $131.8(10.8)^{\mathrm{a}}$ & $136.1(11.8)^{\mathrm{a}}$ & $139.3(10.1)^{\mathrm{a}}$ & $123.1(10.1)^{\mathrm{a}}$ & $144(10.1)^{\mathrm{a}}$ \\
NADP-MD &
\end{tabular}

Data are reported as nmol of substrate (NADPH) transformed in NADP $\cdot \mathrm{min}^{-1} \cdot \mathrm{mg}$ cytosol protein ${ }^{-1}$, for FAS. For G-6PDH, 6-PGDH and NADP-MD, data are reported as nmol of substrate (NADPH) produced $\cdot \mathrm{min}^{-1} \cdot \mathrm{mg}^{-1}$ cytosol protein ${ }^{-1}$. FAS: fatty acid synthase; G-6PDH: glucose 6-phosphate dehydrogenase; 6-PGDH: 6-phosphogluconate dehydrogenase; NADP-MD: NADP-malate dehydrogenase. For other abbreviations, see legend to Table 2. Different letters in the same row indicate statistically significant difference $(\mathrm{P}<0.05)$, with exception of FAS, interaction with $\mathrm{C} \times \mathrm{pGH}(\mathrm{P}<0.10)$.

Table 4. Values of fatty acid synthase (FAS) mRNA abundance in adipose tissue cultures incubated for 24 and $48 \mathrm{~h}$.

\begin{tabular}{lccccc}
\hline mRNA & \multicolumn{3}{c}{ Treatment } \\
\cline { 2 - 6 } & $\mathrm{C}$ & $\mathrm{pGH}$ & $\mathrm{LA}$ & CLA50 & CLA200 \\
\hline $24 \mathrm{~h}$ & - & 0.90 & 1.38 & 0.62 & 0.65 \\
$48 \mathrm{~h}$ & - & 0.60 & 0.37 & 0.50 & 0.43 \\
\hline
\end{tabular}

Values of FAS transcripts normalized for $\beta$-actin, after 24 and $48 \mathrm{~h}$ of culture and expressed relative to the control (100 $\mu \mathrm{M}$ polyvinyl alcohol) $(\mathrm{P}>0.05)$. For abbreviations, see legend to Table 2 .

The reduction of the FAS activity by both CLA200 and pGH was not accompanied by reduction in the activity of the pentose pathway enzymes (i.e., production of NADPH) (Table 3). This response is similar to that observed when GH is administered to dairy cows, despite the pronounced inhibitory effect on lipid synthesis (Lanna, 1993). This suggests that the abundance of these enzymes is such that they do not have a regulator role in these biochemical pathways.

The inhibitory effect of trans-10, cis-12 CLA on FAS mRNA abundance is consistent with data from another study, mainly in mammary gland tissue (Matitashvili et al., 2001). Coherent with the reduction in FAS enzymatic activity after $48 \mathrm{~h}$, the treatment with $200 \mu \mathrm{M}$ CLA caused a reduction of $22 \%$ in relation to the first $24 \mathrm{~h}$ of culture. It suggests that the possible CLA effects on lipid metabolism can take longer to occur.

In experiments where alterations were observed in the mRNA abundance of the enzymes involved in the metabolism of lipids, the diets containing trans-10, cis-12 CLA were fed over a longer period of time (3 weeks). After 3 weeks of CLA supplementation, Peterson et al. (2003) observed reductions in both FAS and acetyl-coenzyme A carboxylase (ACC) mRNA abundance in biopsies of the mammary gland tissue of lactating cows, which occurred simultaneously with a reduction in milk fat secretion. In contrast, Choi et al. (2000) observed no alterations in FAS mRNA expression when immature 3T3-L1 adipocytes were cultured with trans-10, cis-12 CLA. In a previous study, where the effects of pGH were evaluated under the same conditions, José et al. (2006) observed a reduction of $22 \%$ in FAS enzymatic activity, which was accompanied by 
$\sim 70 \%$ of reduction in mRNA abundance after $48 \mathrm{~h}$ of incubation. In the present study, the effects were similar in direction, but of different magnitude. The difference between the half-life of the FAS protein (i.e., around $48 \mathrm{~h}$ ) and its corresponding mRNA (i.e., 3 to $5 \mathrm{~h}$; Back et al., 1986) suggests that a larger difference would be expected for mRNA abundance in relation to protein.

Baumgard et al. (2002) observed a reduction in FAS, ACC and SCD mRNA abundance in the mammary gland from cows abomasally infused with trans-10, cis-12 CLA for 5 days. Similarly, Lin et al. (2004) observed a reduction in ACC activity and mRNA abundance in the mammary gland of lactating female rats fed trans-10, cis-12 CLA from 4 to 15 days postpartum. The FAS mRNA abundance was also reduced in response to CLA, but its enzyme activity remained unchanged. Unlike that observed in the mammary gland, the activities and mRNA abundance for both ACC and FAS in the liver were not affected by CLA treatment (Lin et al., 2004). Hayashi et al. (2007) observed a reduced activity of the FAS, G-6PDH and 6-PGDH enzymes in the liver and mammary gland of female rats fed diets supplemented with CLA60 ( $\sim 35 \%$ of trans- 10 , cis-12 CLA) from the 1st to the 15th day postpartum. In the adipose tissue, however, only the FAS activity was reduced in response to CLA, which corroborates data from the present study. A lower FAS activity was also observed in the mammary gland of cows abomasally infused with trans-10, cis-12 CLA (Piperova et al., 2000). In general, data from several studies suggest that mammary gland is more responsive to trans-10, cis-12 CLA than adipose tissue. As observed in the present study, Hayashi et al. (2007) did not observe any difference in the activities of the NADPH-generating enzymes of the pentose pathway in the adipose tissue of lactating rats. According to Mersmann (2001), responses to CLA can vary among species due to differences in lipid metabolism, making comparisons somewhat complicated. For instance, liver is the most important site of lipid synthesis in rodents, whereas is swine, it occurs mainly in adipose tissue.

Corino et al. (2003) observed that NADP-MD and G-6PDH activities were unchanged in the adipose tissue of swine fed a mixture of CLA isomers, but ACC activity was decreased. In contrast, Bee (2000) observed an increase in G-6PDH and NADP-MD activities in the adipose tissue when swine were fed a mixture of CLA isomers. These changes were not accompanied by increases in the FAS activity.

The effects of the treatments on lipolysis, after a 48-h culture, were appraised for the release of NEFA during a 2-h period of baseline and isoproterenol incubation (Table 5). There were effects with both treatments $(\mathrm{P}<0.001)$ and stimulus $(\mathrm{P}<0.001)$, but interaction between treatment and stimulus was not significant $(\mathrm{P}>0.05)$.

\begin{tabular}{|c|c|c|c|c|c|c|c|c|c|}
\hline & \multicolumn{9}{|c|}{ Treatment $\left(\right.$ NEFA $\left.\mu \mathrm{mol} \cdot \mathrm{g}^{-1} \cdot 2 \mathrm{~h}^{-1}\right)$} \\
\hline & \multicolumn{2}{|c|}{$\mathrm{C}$} & pGH & LA & \multicolumn{2}{|c|}{ CLA50 } & \multicolumn{2}{|c|}{ CLA200 } & $\mathrm{M}^{1}$ \\
\hline Baseline & \multicolumn{2}{|c|}{$1.85(0.73)$} & $3.65(0.69)$ & $1.34(0.69)$ & \multicolumn{2}{|c|}{$1.30(0.69)$} & \multicolumn{2}{|c|}{$1.92(0.69)$} & 2.01 \\
\hline Isoproterenol & \multicolumn{2}{|c|}{$4.85(1.4)$} & $9.00(0.73)$ & $3.34(0.69)$ & \multicolumn{2}{|c|}{$4.24(0.69)$} & \multicolumn{2}{|c|}{$5.54(0.9)$} & 5.39 \\
\hline \multicolumn{10}{|c|}{ Effects } \\
\hline $\mathrm{C}$ & CLA200 & CLA200 & CLA200 & $\mathrm{C}$ & CLA50 & CLA50 & $\mathrm{C}$ & LA & $\mathrm{C}$ \\
\hline $\mathrm{x}$ & $\mathrm{x}$ & $\mathrm{x}$ & $\mathrm{x}$ & $\mathrm{x}$ & $\mathrm{x}$ & $\mathrm{x}$ & $\mathrm{x}$ & $\mathrm{x}$ & $\mathrm{x}$ \\
\hline CLA200 & CLA50 & LA & pGH & CLA50 & LA & pGH & LA & pGH & pGH \\
\hline Ns & Ns & Ns & $*$ & Ns & Ns & $* *$ & Ns & $* *$ & $*$ \\
\hline
\end{tabular}

Data are reported as means (SD) from cultures of adipose tissue explants $(\mathrm{N}=9)$. ${ }^{1}$ Lipolysis values of non-esterified fatty acid (NEFA) release over a 2-h incubation in the presence or absence of isoproterenol. For abbreviations, see legend to Table 2 . Different probability between treatments $(* \mathrm{P}<0.05 ; * * \mathrm{P}<0.01$; Ns: $\mathrm{P}>0.05)$. 
The pGH treatment induced an increase in NEFA mobilization regardless of stimulus, which is consistent with its well-established stimulatory effect on lipolysis. These results indicate that lipolytic mechanisms of the explants in culture were capable of responding to the treatments. NEFA mobilization was unchanged by CLA treatments. In 3T3-L1 adipocytes treated with trans-10, cis-12 CLA for 6 days, an increase of $18 \%$ was observed in baseline lipolysis, measured by glycerol release in relation to the control. There was also a 300-fold increase in glycerol release in lipolysis stimulated with isoproterenol and adenosine deaminase. In contrast, cis-9, trans-11 CLA caused a decrease of $11 \%$ in glycerol release in the medium (Evans et al., 2002). In hamsters fed diets supplemented with the trans-10, cis-12 CLA for 28 days, there was a decrease in the absorption of fat in the intestine and a possible increase of lipolysis in the liver, greater than in the adipose tissue under isoenergetic conditions (Bissonauth et al., 2006). In contrast with these results and consistent with those obtained in the present study, lipolysis in primary cell cultures of the vascular stroma of human adipose tissue was unaltered by either trans-10, cis-12 or cis-9, trans-11 CLA isomers, after a 3-day period of supplementation (Brown et al., 2001). The lack of trans-10, cis-12 CLA effect on lipolysis observed in the present study and others (Brown et al., 2001; Perfield et al., 2002; Xu et al., 2003) suggests that mechanisms by which this CLA isomer decreases fat accretion in growing animals are based mainly on an inhibited lipogenesis instead of a stimulated lipolysis.

\section{CONCLUSIONS}

The in vitro system was shown to respond normally to positive control (growth hormone), as indicated by decreased lipogenesis, increased lipolysis and decreased FAS activity and transcripts, suggesting that this system was adequate to perform the CLA tests.

The CLA200 treatment decreased FAS activity and transcripts when compared to linoleic acid. Lipid mobilization was unchanged by trans-10, cis-12 CLA.

\section{ACKNOWLEDGMENTS}

The authors thank Dr. Dale Bauman and Dr. Lance Baumgard for conjugated linoleic acid and Dr. Irineu U. Packer for helping with statistical analysis.

\section{REFERENCES}

Back DW, Goldman MJ, Fisch JE, Ochs RS, et al. (1986). The fatty acid synthase gene in avian liver. Two mRNAs are expressed and regulated in parallel by feeding, primarily at the level of transcription. J. Biol. Chem. 261: 4190-4197.

Bauman DE and Davis CL (1975). Regulation of lipid metabolism. In: Digestion and Metabolism in the Ruminant (McDonald IW and Warner ACI, eds.). Butterworths, London, 67-83.

Bauman DE, Brown RE and Davis CL (1970). Pathways of fatty acid synthesis and reducing equivalent generation in mammary gland of rat, sow, and cow. Arch. Biochem. Biophys. 140: 237-244.

Baumgard LH, Corl BA, Dwyer DA, Saebo A, et al. (2000). Identification of the conjugated linoleic acid isomer that inhibits milk fat synthesis. Am. J. Physiol. Regul. Integr. Comp. Physiol. 278: R179-R184.

Baumgard LH, Matitashvili E, Corl BA, Dwyer DA, et al. (2002). trans-10, cis-12 conjugated linoleic acid decreases lipogenic rates and expression of genes involved in milk lipid synthesis in dairy cows. J. Dairy Sci. 85: 2155-2163.

Bee G (2000). Dietary conjugated linoleic acids alter adipose tissue and milk lipids of pregnant and lactating sows. J. Nutr. 130: 2292-2298.

Bissonauth V, Chouinard Y, Marin J, Leblanc N, et al. (2006). The effects of t10,c12 CLA isomer compared with c9,t11 CLA isomer on lipid metabolism and body composition in hamsters. J. Nutr. Biochem. 17: 597-603. 
Brown JM and McIntosh MK (2003). Conjugated linoleic acid in humans: regulation of adiposity and insulin sensitivity. J. Nutr. 133: 3041-3046.

Brown JM, Halvorsen YD, Lea-Currie YR, Geigerman C, et al. (2001). Trans-10, cis-12, but not cis-9, trans-11, conjugated linoleic acid attenuates lipogenesis in primary cultures of stromal vascular cells from human adipose tissue. J. Nutr. 131: 2316-2321.

Choi Y, Kim YC, Han YB, Park Y, et al. (2000). The trans-10,cis-12 isomer of conjugated linoleic acid downregulates stearoyl-CoA desaturase 1 gene expression in 3T3-L1 adipocytes. J. Nutr. 130: 1920-1924.

Chouinard PY, Corneau L, Barbano DM, Metzger LE, et al. (1999). Conjugated linoleic acids alter milk fatty acid composition and inhibit milk fat secretion in dairy cows. J. Nutr. 129: 1579-1584.

Corino C, Magni S, Pastorelli G, Rossi R, et al. (2003). Effect of conjugated linoleic acid on meat quality, lipid metabolism, and sensory characteristics of dry-cured hams from heavy pigs. J. Anim. Sci. 81: 2219-2229.

Dugan MER, Aalhus JL, Schaefer AL and Kramer JKG (1997). The effect of conjugated linoleic acid on fat to lean repartitioning and feed conversion in pigs. Can. J. Anim. Sci. 77: 723-725.

Dugan MER, Aalhus JL, Jeremiah LE, Kramer JKG, et al. (1999). The effects of feeding conjugated linoleic acid on subsequent pork quality. Can. J. Anim. Sci. 79: 45-51.

Etherton TD, Donkin SS and Bauman DE (1995). Mechanisms by which porcine somatotropin (pST) decreases adipose tissue growth in growing pigs. In: The Biology of Fat in Meat Animals (Smith SB and Smith DR, eds.). Am. Soc. Anim. Sci., Champaign, 53-69.

Evans M, Lin X, Odle J and McIntosh M (2002). Trans-10, cis-12 conjugated linoleic acid increases fatty acid oxidation in 3T3-L1 preadipocytes. J. Nutr. 132: 450-455.

Folch J, Lees M and Sloane Stanley GH (1957). A simple method for the isolation and purification of total lipides from animal tissues. J. Biol. Chem. 226: 497-509.

Giesy JG, Hanson TW, Robinson M, Hafliger HC, et al. (1999). Effects of calcium salts of conjugated linoleic acid (CLA) on milk yield, fat and CLA content in milk fat in Holstein cows early in lactation. J. Dairy Sci. 82: 83.

Glock GE and McLean P (1953). Further studies on the properties and assay of glucose 6-phosphate dehydrogenase and 6-phosphogluconate dehydrogenase of rat liver. Biochem. J. 55: 400-408.

Gornall AG, Bardawill CJ and David MM (1949). Determination of serum proteins by means of the biuret reaction. $J$. Biol. Chem. 177: 751-766.

Hayashi AA, de Medeiros SR, Carvalho MH and Lanna DP (2007). Conjugated linoleic acid (CLA) effects on pups growth, milk composition and lipogenic enzymes in lactating rats. J. Dairy Res. 74: 160-166.

Ingle DL, Bauman DE, Mellenberger RW and Johnson DE (1973). Lipogenesis in the ruminant: effect of fasting and refeeding on fatty acid synthesis and enzymatic activity of sheep adipose tissue. J. Nutr. 103: 1479-1488.

José AAFBV, Alvares LE, Delgado EF, Coutinho LL, et al. (2006). Effect of growth hormone on fatty acid synthase gene expression in porcine adipose tissue cultures. Genet. Mol. Biol. 29: 180-186.

José AA, Gama MA, Urban A, Merighe GK, et al. (2007). Evaluation of polyvinyl alcohol for fatty acid supplementation in adipose tissue explant culture. Genet. Mol. Res. 6: 214-221.

Lanna DPD (1993). Cellular mechanisms of somatotropin control of lipogenesis and lipolysis in adipose tissue of lactating and growing animals. $\mathrm{PhD}$ thesis, Cornell University, Ithaca.

Lanna DP and Bauman DE (1999). Effect of somatotropin, insulin, and glucocorticoid on lipolysis in chronic cultures of adipose tissue from lactating cows. J. Dairy Sci. 82: 60-68.

Lanna DPD, Dwyer DA and Bauman DE (1994). Somatotropin and the control of lipogenesis by insulin and adenosine in pig adipose tissue. J. Anim. Sci. 72: 161.

Lanna DP, Houseknecht KL, Harris DM and Bauman DE (1995). Effect of somatotropin treatment on lipogenesis, lipolysis, and related cellular mechanisms in adipose tissue of lactating cows. J. Dairy Sci. 78: 1703-1712.

Lee KN, Pariza MW and Ntambi JM (1998). Conjugated linoleic acid decreases hepatic stearoyl-CoA desaturase mRNA expression. Biochem. Biophys. Res. Commun. 248: 817-821.

Lin X, Loor JJ and Herbein JH (2004). Trans10, cis12-18:2 is a more potent inhibitor of de novo fatty acid synthesis and desaturation than cis9,trans11-18:2 in the mammary gland of lactating mice. J. Nutr. 134: 1362-1368.

Littell RC, Milliken GA, Stroup WW and Wolfinger RD (1996). SAS system for mixed models. Statistical Analysis System Institute, Cary.

Matitashvili E, Baumgard LH and Bauman DE (2001). The effect of trans-10, cis-12 conjugated linoleic acid (CLA) infusion on milk fat synthesis and expression of lipogenic enzymes in the mammary gland of lactating cows. J. Anim. Sci. 79: 310 .

Medeiros SR, Oliveira DE, Aroeira LJM, McGuire MA, et al. (2000). The effect of long-term supplementation of conjugated linoleic acid (CLA) to dairy cows grazing tropical pasture. J. Dairy Sci. 83: 169.

Genetics and Molecular Research 7 (2): 284-294 (2008)

CFUNPEC-RP www.funpecrp.com.br 
Mersmann HJ (2001). Mechanisms for conjugated linoleic acid-mediated reduction in fat deposition. J. Anim. Sci. 80: E126-E134.

Ostrowska E, Muralitharan M, Cross RF, Bauman DE, et al. (1999). Dietary conjugated linoleic acids increase lean tissue and decrease fat deposition in growing pigs. J. Nutr. 129: 2037-2042.

Pariza MW, Ashoor SH, Chu FS and Lund DB (1979). Effects of temperature and time on mutagen formation in pan-fried hamburger. Cancer Lett. 7: 63-69.

Park Y, Albright KJ, Liu W, Storkson JM, et al. (1997). Effect of conjugated linoleic acid on body composition in mice. Lipids 32: 853-858.

Park Y, Storkson JM, Albright KJ, Liu W, et al. (1999). Evidence that the trans-10,cis-12 isomer of conjugated linoleic acid induces body composition changes in mice. Lipids 34: 235-241.

Park Y, Storkson JM, Ntambi JM, Cook ME, et al. (2000). Inhibition of hepatic stearoyl-CoA desaturase activity by trans-10, cis-12 conjugated linoleic acid and its derivatives. Biochim. Biophys. Acta 1486: 285-292.

Perfield JW, Bernal-Santos G, Overton TR and Bauman DE (2002). Effects of dietary supplementation of rumen-protected conjugated linoleic acid in dairy cows during established lactation. J. Dairy Sci. 85: 2609-2617.

Peterson DG, Matitashvili EA and Bauman DE (2003). Diet-induced milk fat depression in dairy cows results in increased trans-10, cis-12 CLA in milk fat and coordinate suppression of mRNA abundance for mammary enzymes involved in milk fat synthesis. J. Nutr. 133: 3098-3102.

Pfaffl MW (2001). A new mathematical model for relative quantification in real-time RT-PCR. Nucleic Acids Res. 29: e45.

Pfaffl MW, Horgan GW and Dempfle L (2002). Relative expression software tool (REST) for group-wise comparison and statistical analysis of relative expression results in real-time PCR. Nucleic Acids Res. 30: e36.

Piperova LS, Teter BB, Bruckental I, Sampugna J, et al. (2000). Mammary lipogenic enzyme activity, trans fatty acids and conjugated linoleic acids are altered in lactating dairy cows fed a milk fat-depressing diet. J. Nutr. 130: 2568-2574.

SAS Institute (1999). SAS/SAT: user's guide. SAS Intitute Inc., Cary.

Satory DL and Smith SB (1999). Conjugated linoleic acid inhibits proliferation but stimulates lipid filling of murine 3T3-L1 preadipocytes. J. Nutr. 129: 92-97.

Sinnett-Smith PA, Vernon RG and Mayer RJ (1979). Fatty acid synthesis and the activities of fatty acid synthesizing enzymes in rat adiposes tissue during pregnancy and lactation [proceedings]. Biochem. Soc. Trans. 7: 388-389.

Takahashi Y, Kushiro M, Shinohara K and Ide T (2002). Dietary conjugated linoleic acid reduces body fat mass and affects gene expression of proteins regulating energy metabolism in mice. Comp. Biochem. Physiol. B. Biochem. Mol. Biol. 133: 395-404.

Takahashi Y, Kushiro M, Shinohara K and Ide T (2003). Activity and mRNA levels of enzymes involved in hepatic fatty acid synthesis and oxidation in mice fed conjugated linoleic acid. Biochim. Biophys. Acta 1631: 265-273.

Thiel-Cooper RL, Parrish FC Jr, Sparks JC, Wiegand BR, et al. (2001). Conjugated linoleic acid changes swine performance and carcass composition. J. Anim. Sci. 79: 1821-1828.

Tricon S, Burdge GC, Kew S, Banerjee T, et al. (2004). Opposing effects of cis-9, trans-11 and trans-10, cis-12 conjugated linoleic acid on blood lipids in healthy humans. Am. J. Clin. Nutr. 80: 614-620.

Xu X, Storkson J, Kim S, Sugimoto K, et al. (2003). Short-term intake of conjugated linoleic acid inhibits lipoprotein lipase and glucose metabolism but does not enhance lipolysis in mouse adipose tissue. J. Nutr. 133: 663-667. 